\title{
Original Article \\ Peran Tenaga Kesehatan, Promosi Kesehatan dan Dukungan Keluarga Terhadap Pencegahan Anemia pada Ibu Hamil
}

\author{
Madinah Munawaroh ${ }^{1}$, Pinna P.N. Situmorang ${ }^{2}$ \\ 1,2,3 Program Studi Kebidanan Program Sarjana Terapan Departemen Kebidanan \\ Sekolah Tinggi Ilmu Kesehatan Indonesia Maju \\ Jln. Harapan No.50, Lenteng Agung - Jakarta Selatan 12610
}

Email: madinahmh21@gmail.com ${ }^{1}$

\begin{abstract}
A B S T R A C T
Editor: ALR

Diterima: 14/10/2021

Direview: 23/11/2021

Publish: 01/12/2021

Hak Cipta:

(C)2021 Artikel ini memiliki akses terbuka dan dapat didistribusikan berdasarkan ketentuan Lisensi Atribusi Creative Commons, yang memungkinkan penggunaan, distribusi, dan reproduksi yang tidak dibatasi dalam media apa pun, asalkan nama penulis dan sumber asli disertakan. Karya ini dilisensikan di bawah Lisensi Creative Commons Attribution Share Alike 4.0 Internasional.

Introduction: Anemia is one of the most common nutritional disorders during pregnancy, this anemia can be achieved with iron supplementation. Pregnant women who suffer from severe anemia can increase the risk of maternal and infant morbidity and mortality, the possibility of giving birth to babies with low birth weight.

Objectives: The purpose of the study was to determine the relationship between health promotion, the role of health workers, and family support with the prevention of anemia in pregnant women in the working area of the Bondongan Health Center, Bogor City in 2019.

Method: This type of research, quantitative and analytical descriptive approach uses the cross-sectional method. The study population was all pregnant women as many as 128 people and a sample of 56 respondents. The sampling technique is purposive sampling. The measuring instrument uses a questionnaire. Data analysis using chisquare with 0.05 .

Result: The results showed that the prevention of anemia in pregnant women was in the poor category $(57 \%)$, the role of health workers was not good $(55 \%)$, health promotion was not good $(63 \%)$, low family support $(54 \%)$ in preventing anemia in pregnant women working area of Bondongan Health Center, Bogor City in 2019.

Conclusion: There is a significant relationship between the role of health workers (P-value 0.04), Health Promotion (P-value 0.012), and Family Support (P-value 0.02) on the prevention of anemia in pregnant mothers.
\end{abstract}

Keywords: anemia, family, health promotion, health workers 


\section{SIMFISIS Jurnal Kebidanan Indonesia}

eISSN 2807-3770

Volume 01, Nomor 02, November 2021

\section{Pendahuluan}

Pembangunan kesehatan adalah upaya yang dilaksanakan oleh semua komponen bangsa yang bertujuan untuk meningkatkan kesadaran, kemauan, dan kemampuan hidup sehat bagi setiap orang agar peningkatan derajat kesehatan masyarakat yang setinggi-tingginya dapat terwujud. Derajat kesehatan masyarakat dapat dilihat dari berbagai indikator, yang meliputi indikator usia harapan hidup, angka kematian, angka kesakitan, dan status kesehatan gizi masyarakat. ${ }^{1}$

Angka Kematian Ibu (AKI) merupakan salah satu indikator keberhasilan layanan kesehatan di suatu negara. World Health Organization (WHO) tahun 2014 melaporkan bahwa, $20 \%$ dari 515.000 kematian maternal diseluruh dunia disebabkan oleh anemia. Kejadian anemia di dunia menduduki urutan ke tiga dengan prevalensi anemia pada ibu hamil sebesar 74\%. Prevalensi anemia pada ibu hamil di Asia Tenggara 48,2\%. Prevalensi anemia di Asia bervariasi diantaranya, Thailand sebesar 39\% dan India sebesar 85,5\%. Menurut WHO 40\% kematian ibu dinegara berkembang berkaitan dengan anemia dalam kehamilan. ${ }^{2}$

Penyebab kematian ibu di Indonesia tahun 2013 menurut Direktorat Kesehatan Keluarga (KESGA) adalah perdarahan dengan persentase sebesar 30,3\%. Resiko perdarahan ini akan lebih diperberat apabila ibu hamil menderita anemia pada kehamilannya. Berdasarkan data Riset Kesehatan Dasar (Riskesdas) Tahun 2013 yang dilakukan Badan Penelitian Kesehatan (Litbangkes) prevalensi anemia pada ibu hamil anemia dengan kadar $\mathrm{Hb}$ kurang dari $11 \mathrm{gr} / \mathrm{dl}$ sebesar 37,1\%. Anemia pada kehamilan merupakan masalah nasional karena mencerminkan nilai kesejahteraaan sosial ekonomi masyarakat, dan pengaruhnya sangat besar terhadap kualitas sumber daya manusia. Anemia pada kehamilan disebut "potential danger to mother and child" (potensial membahayakan ibu dan anak), karena itulah anemia memerlukan perhatian serius dari semua pihak yang terkait dalam pelayanan kesehatan pada lini terdepan. ${ }^{3}$

Anemia defisiensi besi merupakan salah satu gangguan gizi yang paling sering terjadi selama kehamilan anemia ini dapat dicegah dengan zat besi. Jenis anemia lain dapat disebabkan oleh defisiensi asam folat dan vitamin B12. Anemia defisiensi besi adalah anemia yang disebabkan oleh kurangnya zat besi dalam tubuh, sehingga kebutuhan zat besi (Fe) untuk eritropoesis tidak cukup, yang ditandai dengan gambaran sel darah merah hipokrommikrositer, kadar besi serum (Serum Iron $=$ SI) dan jenuh transferin menurun, kapasitas ikat besi total (Total Iron Binding Capacity/TIBC) meninggi dan cadangan besi dalam sumsum tulang serta ditempat yang lain sangat kurang atau tidak ada sama sekali. Banyak faktor yang dapat menyebabkan timbulnya anemia defisiensi besi antara lain, kurangnya asupan zat besi dan protein dari makanan, konsumsi makanan zat penghambat absorbi zat besi, adanya gangguan absorbsi di usus, perdarahan akut maupun kronis, dan meningkatnya kebutuhan zat besi seperti pada wanita hamil. ${ }^{3}$

Faktor-faktor yang mempengaruhi pencegahan anemia pada ibu hamil adalah tingginya promosi kesehatan dalam memberikan penyuluhan pencegahan anemia pada ibu hamil, peran tenaga kesehatan yang baik, dan dukungan keluarga yang baik dalam mengkonsumsi tablet zat besi. Faktor paling dominan mempengaruhi pencegahan anemia pada ibu hamil adalah Promosi kesehatan tentang pencegahan anemia, baik sasaran, fungsi maupun manfaat pencegahan. ${ }^{5}$

Promosi kesehatan merupakan sebuah proses untuk membuat orang mampu meningkatkan kontrol dan memperbaiki kesehatannya sendiri. Masyarakat mampu untuk 


\section{SIMFISIS Jurnal Kebidanan Indonesia}

melakukan kontrol terhadap aspek-aspek kehidupan yang mempengaruhi kesehatan. Pemberdayaan dilakukan melalui peningkatan pengetahuan, peningkatan dukungan keluarga dan perilaku melalui advokasi, bina suasana dan gerakan masyarakat. Salah satu metode pendidikan kesehatan yang diterapkan pada pencegahan anemia pada ibu hamil adalah promosi kesehatan. Promosi kesehatan melalui konseling membantu merubah perilaku dan meningkatkan pengetahuan untuk pencegahan anemia sehingga dapat mencegah penularan terutama dari ibu ke anak. Promosi kesehatan yang diberikan dilakukan secara berkelanjutan dan continue dengan harapan anemia dapat dicegah sampai datangnya persalinan. ${ }^{1}$

dukungan keluarga juga merupakan salah satu faktor yang mempengaruhi pencegahan anemia pada ibu hamil. dukungan keluarga sebagai kesatuan komunitas yang terkecil juga akan menerima beban mental yang cukup berat. Sangat penting bagi keluarga untuk memberikan dukungan, kasih sayang, perhatian dan dukungan keluarga yang baik bagi ibu hamil yang terindikasi penyakit anemia selama kehamilannya. dukungan keluarga membuat ibu hamil bisa lebih mengatur pola hidupnya. Sehingga ibu hamil dapat menikmati kenyamanan di rumah, pola makan teratur dan hati yang bahagia. Tentu hal tersebut akan mencegah penyakit-penyakit yang datang saat kehamilan termasuk salah satunya penyakit anemia. $^{7}$

Berdasarkan studi pendahuluan yang dilakukan di Puskesmas Bondongan, diketahui dari 14 orang ibu hamil yang memeriksakan kehamilannya di Puskesmas Bondongan dan diwawancarai mengenai tablet zat besi, diperoleh hasil 4 orang diantaranya mempunyai tingkat pengetahuan yang baik dan 10 orang lainnya mempunyai tingkat pengetahuan yang kurang baik.

Peran tenaga kesehatan menurut 7 orang ibu hamil (70\%) menyatakan bahwa mereka tidak pernah mendapatkan informasi terkait efek samping yang akan ditimbulkan setelah mengkonsumsi tablet zat besi, dampak jika tidak mengkonsumsi tablet zat besi dan tenaga kesehatan tidak pernah menganjurkan untuk menghabiskan tablet zat besi $\geq 90$ tablet selama kehamilan. Tiga orang ibu hamil (30\%), mengaku mendapatkan informasi terkait efek samping yang akan ditimbulkan setelah mengkonsumsi tablet zat besi, dampak jika tidak mengkonsumsi tablet zat besi dan jumlah tablet zat besi yang harus dihabiskan selama kehamilan dari buku KIA dan internet.

Tujuan penelitian ini adalah untuk mengetahui hubungan promosi kesehatan, peran tenaga kesehatan dan dukungan keluarga dengan pencegahan anemia pada ibu hamil di wilayah kerja Puskesmas Bondongan Kota Bogor Tahun 2019.

\section{Metode}

Penelitian ini adalah penelitian survei yang bersifat analitik dengan desain cross sectional. Penelitian ini dilakukan di wilayah kerja Puskesmas Bondongan Kota Bogor pada bulan Januari 2020.

Populasi dalam penelitian ini adalah semua ibu hamil di wilayah kerja Puskesmas Bondongan Kota Bogor selama periode Juli - Desember 2019 sebanyak 128 orang. Sampel dalam penelitian ini adalah bersalin sebanyak 56 orang dengan teknik pengambilan sampel yaitu purposive sampling. Teknik pengumpulan data secara kuantitatif dengan menggunakan data primer dan data sekunder yang diambil dari data ibu balita di Kelurahan Bondongan. Instrumen penelitian adalah alat-alat yang akan digunakan untuk pengumpulan data. Metode 
pengumpulan data dalam penelitian ini menggunakan data primer. Instrumen yang digunakan dalam penelitian ini adalah kuesioner atau angket. Kuesioner atau angket adalah daftar pertanyaan yang sudah tersusun dengan baik, sudah matang, dimana responden tinggal memberikan jawaban dengan menggunakan tanda-tanda tertentu. Kuesioner yang digunakan dalam penelitian ini menggunakan jenis pertanyaan tertutup. Responden hanya memberi tanda ceklis $(\sqrt{ })$ pada jawaban yang telah dipilih.

Analisis yang digunakan analisis bivariat yaitu digunakan untuk mengetahui ada tidaknya hubungan variabel independen dengan variabel dependen, serta untuk melakukan identifikasi variabel yang bermakna menggunakan uji statistic chi-square. Chi-Square yaitu pengujian hipotesis mengenai perbandingan antara frekuensi observasi atau yang benar-benar terjadi atau actual dengan frekuensi harapan. Rumus Chi-Square dalam penelitian ini dengan penggunaan derajat kemaknaan 95\%, artinya apabila $p$-value kurang dari 0,05 ( $p$-value $<0,05$ ) berarti secara signifikan ada hubungan antara variabel independen dan dependen, dan apabila $p$-value lebih dari 0,05 ( $p$-value $\geq 0,05)$ berarti tidak ada hubugan antara variabel independen dan dependen.

\section{Hasil}

Hasil penelitian ini dibagi tiga bagian yaitu, karakteristik responden, analisa univariat yaitu frekuensi peran tenaga kesehatan, promosi kesehatan, dukungan keluarga dan pencegahan anemia pada ibu hamil. Analisa bivariat yang digunakan adalah uji Chi Square yaitu apakah ada hubungan peran tenaga kesehatan, promosi kesehatan dan dukungan keluarga terhadap pencegahan anemia pada ibu hamil di wilayah kerja Puskesmas Bondongan Kota Bogor Tahun 2019.

Tabel 1. Distribusi frekuensi promosi kesehatan, peran tenaga kesehatan, dukungan keluarga dan pencegahan anemia pada ibu hamil di wilayah kerja Puskesmas Bondongan Kota Bogor Tahun 2019

\begin{tabular}{lcc}
\hline \multicolumn{1}{c}{ Variabel } & $\begin{array}{c}\text { Jumlah } \\
(\mathbf{n})\end{array}$ & $\begin{array}{c}\text { Presentasi } \\
(\%)\end{array}$ \\
\hline $\begin{array}{l}\text { Pencegahan anemia } \\
\quad \text { Kurang }\end{array}$ & 32 & 57 \\
$\quad$ Baik & 24 & 43 \\
Peran Tenaga Kesehatan & & \\
$\quad$ Kurang & 31 & 55 \\
$\quad$ Baik & 25 & 45 \\
Promosi Kesehatan & & \\
$\quad$ Kurang & 35 & 63 \\
$\quad$ Baik & 21 & 37 \\
Dukungan Keluarga & & \\
$\quad$ Rendah & 30 & 54 \\
$\quad$ Tinggi & 26 & 46 \\
\hline
\end{tabular}

Analisis univariat yang dilakukan bertujuan untuk mengetahui distribusi frekuensi dari masing-masing variabel yang diteliti, yaitu frekuensi peran tenaga kesehatan, promosi kesehatan, dukungan keluarga dan pencegahan anemia pada ibu hamil.

Diketahui sebanyak 32 orang (57\%) responden memiliki pencegahan anemia pada ibu hamil kurang baik. Sedangkan sebanyak 24 orang (43\%) responden memiliki pencegahan anemia pada ibu hamil baik. Sebanyak 31 orang (55\%) responden berpendapat peran tenaga kesehatan kurang baik dalam memberikan penyuluhan tentang pencegahan anemia pada ibu 


\section{SIMFISIS Jurnal Kebidanan Indonesia}

Volume 01, Nomor 02, November 2021

hamil. Sebanyak 25 orang (45\%) responden berpendapat peran tenaga kesehatan sudah baik dalam memberikan penyuluhan tentang pencegahan anemia pada ibu hamil. Sebanyak 35 orang $(63 \%)$ responden menyatakan bahwa promosi kesehatan kurang baik dalam pemeriksaan skrining anemia dan penyampaian program pencegahan anemia. Sedangkan sebanyak 21 orang (38\%) responden menyatakan bahwa promosi kesehatan sudah baik dalam pemeriksaan skrining anemia dan penyampaian program pencegahan anemia. Sebanyak 30 orang (54\%) responden memiliki dukungan keluarga yang rendah dalam pencegahan anemia pada ibu hamil. Sedangkan sebanyak 26 orang (46\%) responden memiliki dukungan keluarga yang tinggi dalam pencegahan anemia pada ibu hamil.

Tabel 2. Hubungan peran Tenaga Kesehatan, Promosi Kesehatan dan Dukungan Keluarga terhadap Pencegahan Anemia pada ibu hamil di wilayah kerja Puskesmas Bondongan Kota Bogor Tahun 2019

\begin{tabular}{|c|c|c|c|c|c|c|c|}
\hline \multirow{3}{*}{ Variabel } & \multicolumn{4}{|c|}{ Pencegahan Anemia } & \multirow{3}{*}{ Total } & \multirow{3}{*}{$\begin{array}{c}\text { P- } \\
\text { Value }\end{array}$} & \multirow{3}{*}{ OR } \\
\hline & \multicolumn{2}{|c|}{ Kurang } & \multicolumn{2}{|c|}{ Baik } & & & \\
\hline & $\mathbf{N}$ & $\%$ & $\mathbf{N}$ & $\%$ & & & \\
\hline \multicolumn{8}{|c|}{ Peran Tenaga Kesehatan } \\
\hline Kurang & 22 & $71 \%$ & 9 & $29 \%$ & 31 & \multirow{2}{*}{0,04} & 3,67 \\
\hline Baik & 10 & $40 \%$ & 15 & $60 \%$ & 25 & & $(1,20-11,17)$ \\
\hline \multicolumn{8}{|c|}{ Promosi Kesehatan } \\
\hline Kurang & 25 & $71 \%$ & 10 & $29 \%$ & 35 & \multirow{2}{*}{0,012} & \multirow{2}{*}{$\begin{array}{c}5,0 \\
(1,56-15,8)\end{array}$} \\
\hline Baik & 7 & $33 \%$ & 14 & $67 \%$ & 21 & & \\
\hline \multicolumn{8}{|c|}{ Dukungan Keluarga } \\
\hline Rendah & 23 & $77 \%$ & 7 & $23 \%$ & 30 & \multirow{2}{*}{0,02} & \multirow{2}{*}{$\begin{array}{c}7,56 \\
(2,16-26,5)\end{array}$} \\
\hline Tinggi & 7 & $26 \%$ & 19 & $74 \%$ & 26 & & \\
\hline
\end{tabular}

Tabel 2 menunjukan bahwa peran tenaga kesehatan terhadap Pencegahan anemia pada ibu hamil 31 responden berpendapat peran tenaga Kesehatan kurang baik. Sebanyak 22 responden (71\%) memiliki pencegahan anemia kurang baik dan 9 responden (29\%) lainnya memiliki pencegahan anemia baik Sedangkan 25 responden berpendapat peran tenaga Kesehatan sudah baik. Sebanyak 10 responden (40\%) kurang baik dalam pencegahan anemia dan 15 responden $(60 \%)$ baik dalam pencegahan anemia. Hasil uji statistik chi square hubungan peran tenaga kesehatan (variabel X1) dengan pencegahan anemia ibu hamil (variable $\mathrm{Y})$ diperoleh nilai $\mathrm{p}=0,04$ artinya $p$-value $\leq$ alpha $(0,05)$. Hasil Uji OR diperoleh nilai $\mathrm{OR}=3,67$.

Tabel 2 menunjukan bahwa promosi kesehatan terhadap pencegahan anemia pada ibu hamil dari 35 responden menyatakan promosi kesehatan kurang baik dalam menyampaikan program pencegahan anemia. Sebanyak 25 responden (71\%) memiliki pencegahan anemia pada ibu hamil kurang baik dan 10 responden (29\%) lainnya memiliki pencegahan anemia pada ibu hamil sudah baik. Sedangkan 21 responden menyatakan promosi kesehatan baik dalam menyampaikan program pencegahan anemia. Sebanyak 7 responden (33\%) memiliki pencegahan anemia kurang baik dan 14 responden (67\%) memiliki pencegahan anemia baik. Hasil uji statistik chi square hubungan promosi kesehatan (variabel X2) dengan pencegahan anemia pada ibu hamil (variable $\mathrm{Y}$ ) diperoleh nilai $\mathrm{p}=0,012$ artinya $p$-value $\leq$ alpha $(0,05)$. Hasil Uji OR diperoleh nilai OR=7,56.

Tabel 2 menunjukan bahwa hubungan dukungan keluarga terhadap pencegahan anemia dari 30 responden memiliki dukungan keluarga yang rendah. Sebanyak 23 responden (77\%) memiliki pencegahan anemia pada ibu hamil kurang baik dan 7 responden $(23 \%)$ lainnya memiliki pencegahan anemia pada ibu hamil baik. Sedangkan 26 responden memiliki 
dukungan keluarga tinggi. Sebanyak 7 responden (26\%) memiliki pencegahan anemia pada ibu hamil kurang baik dan 19 responden (74\%) lainnya memiliki pencegahan anemia pada ibu hamil baik. Hasil uji statistik chi square hubungan dukungan keluarga (variabel X3) dengan pencegahan anemia pada ibu hamil (variabel Y) diperoleh nilai $\mathrm{p}=0,02$ artinya $p$-value $\leq$ alpha (0,05). Hasil Uji diperoleh nilai $\mathrm{OR}=7,56$.

\section{Pembahasan}

\section{Hubungan Peran Tenaga Kesehatan Terhadap Pencegahan Anemia pada Ibu Hamil}

Hasil uji statistik chi square hubungan peran tenaga kesehatan dengan pencegahan anemia pada ibu hamil diperoleh nilai $\mathrm{p}=0,04$ artinya $p$-value $\leq$ alpha $(0,05)$ sehingga dapat disimpulkan hipotesis nol (Ho) ditolak dan hipotesis alternatif (Ha) diterima atau ada hubungan bermakna antara hubungan peran tenaga kesehatan terhadap pencegahan anemia pada ibu hamil di wilayah kerja Puskesmas Bondongan Kota Bogor Tahun 2019.

Hasil uji odd ratio diperoleh nilai $\mathrm{OR}=3,67$ artinya peran tenaga kesehatan kurang baik mempunyai peluang 3,67 kali lebih berperilaku kurang baik dalam pencegahan anemia pada ibu hamil dibandingkan dengan peran tenaga kesehatan yang baik.

Petugas kesehatan sebagai ujung tombak pelayanan kesehatan ibu hamil, kelahiran dan pemeliharaan kesehatan ibu dan anak, memiliki peran cukup strategis dalam upaya menekan laju pertumbuhan penyakit setelah pasca persalinan dan pelayanan KIA/KB. Para tenaga kesehatan dilatih agar memiliki pengetahuan tentang pencegahan anemia pada ibu hamil. ${ }^{4}$ Peran serta tenaga kesehatan untuk meningkatkan perilaku pencegahan anemia diantaranya menggunakan pendekatan persuasif pada ibu dan keluarga dalam memotivasi dan menumbuhkan kesadaran tentang pentingnya tablet zat besi. Tenaga kesehatan perlu meningkatkan pemberian penyuluhan tentang anemia kehamilan dan konsumsi tablet zat besi, sehingga ibu hamil bersedia untuk minum tablet zat besi. ${ }^{11}$

Menurut peneliti peran tenaga kesehatan yang harus lebih dioptimalkan salah satunya adalah bidan. Bidan adalah tenaga kesehatan yang sangat dekat dengan ibu hamil dari awal masa kehamilan, konsultasi ibu hamil sampai dengan melahirkan. Bidan harus lebih meningkatkan perannya dalam menyampaikan pengetahuan dan penyuluhan tentang pencegahan anemia. Setiap keluhan ibu hamil menjadi patokan pula dalam menyampaikan pengetahuan tentang pencegahan penyakit ibu hamil dan solusi-solusi terkait keluhan yang dirasakan ibu hamil.

\section{Hubungan Promosi Kesehatan Terhadap Pencegahan Anemia pada Ibu Hamil}

Hasil uji statistik chi square hubungan ketersediaan fasilitas dengan pencegahan anemia pada ibu hamil diperoleh nilai $\mathrm{p}=0,012$ artinya $p$-value <alpha $(0,05)$ sehingga dapat disimpulakan hipotesis nol (Ho) ditolak dan hipotesis alternativ (Ha) diterima atau ada hubungan serta bermakna antara hubungan promosi kesehatan terhadap pencegahan anemia pada ibu hamil di wilayah kerja Puskesmas Bondongan Kota Bogor Tahun 2019.

Hasil uji odd ratio diperoleh nilai $\mathrm{OR}=5,00$ artinya Promosi Kesehatan yang kurang baik mempunyai peluang 5 kali lebih berperilaku kurang baik dalam pencegahan anemia pada ibu hamil dibandingkan dengan promosi kesehatan yang baik.

Promosi kesehatan merupakan sebuah proses untuk membuat orang mampu meningkatkan kontrol dan memperbaiki kesehatannya sendiri. Masyarakat mampu untuk 


\section{SIMFISIS Jurnal Kebidanan Indonesia}

Volume 01, Nomor 02, November 2021

melakukan kontrol terhadap aspek-aspek kehidupan yang mempengaruhi kesehatan. Pemberdayaan dilakukan melalui peningkatan pengetahuan, peningkatan dukungan keluarga dan perilaku melalui advokasi, bina suasana dan gerakan masyarakat. Salah satu metode pendidikan kesehatan yang diterapkan pada pencegahan anemia pada ibu hamil adalah promosi kesehatan. Promosi kesehatan melalui konseling membantu merubah perilaku dan meningkatkan pengetahuan untuk pencegahan anemua sehingga dapat mencegah penularan terutama dari ibu ke anak. Promosi kesehatan yang diberikan harus dilakukan secara berkelanjutan dan continue dengan harapan anemia dapat dicegah sampai datangnya persalinan. ${ }^{16}$

Hal ini membuktikan teori, bahwa promosi kesehatan merupakan reaksi seseorang dalam membentuk pandangan, mewarnai perasaan dan akan ikut menentukan kecenderungan perilaku individu terhadap manusia lainnya bahkan terhadap diri sendiri fenomena promosi kesehatan yang timbul tidak saja ditentukan oleh keadaan lingkungan yang sedang dihadapi tetapi juga dengan kaitannya dengan pengalaman-pengalaman, oleh situasi di saat sekarang, dan oleh harapan-harapan untuk masa yang akan datang. promosi kesehatan sangat menentukan perilaku seseorang untuk mengarah perubahan. ${ }^{12}$ Promosi kesehatan seseorang berhubungan langsung dengan perilaku. Perilaku merupakan suatu kegiatan atau aktivitas organisme yang bersangkutan. Perilaku manusia adalah suatu aktivitas daripada manusia itu sendiri, sehingga sikap seseorang yang baik akan membentuk perilaku yang baik juga. ${ }^{13}$

Menurut asumsi peneliti promosi kesehatan diperoleh dari pengalaman diri sendiri atau pengalaman orang lain. Promosi kesehatan yang positif akan membentuk perilaku ibu hamil yang baik dalam mempersiapkan persalinan. Promosi kesehatan ibu hamil yang positif akan membantu proses pemeriksaan dan persalinan dengan baik. Sehingga rasa cemas dan takut ibu hamil terhadap penyakit anemia kehamilan dapat dikendalikan dengan baik.

\section{Hubungan Dukungan Keluarga Terhadap Pencegahan Anemia pada Ibu Hamil}

Hasil uji statistik chi square hubungan dukungan keluarga dengan pencegahan anemia pada ibu hamil di peroleh nilai $\mathrm{p}=0,004$ artinya $p$-value $\leq$ alpha $(0,05)$ sehingga dapat disimpulkan hipotesis nol (Ho) ditolak dan hipotesis alternatif (Ha) diterima atau ada hubungan bermakna antara hubungan dukungan keluarga terhadap pencegahan anemia pada ibu hamil di wilayah kerja Puskesmas Bondongan Kota Bogor Tahun 2019.

Hasil uji odd ratio diperoleh nilai $\mathrm{OR}=7,56$ artinya dukungan keluarga yang rendah mempunyai peluang 7,56 kali lebih berperilaku kurang baik dalam pencegahan anemia pada ibu hamil dibandingkan dengan dukungan keluarga yang tinggi.

Dukungan keluarga juga merupakan salah satu faktor yang mempengaruhi pencegahan anemia pada ibu hamil. Dukungan keluarga sebagai kesatuan komunitas yang terkecil juga akan menerima beban mental yang cukup berat. Sanggat penting bagi keluarga untuk memberikan dukungan, kasih sayang, perhatian dan dukungan keluarga yang baik bagi ibu hamil yang terindikasi penyakit anemia selama kehamilannya. Dukungan keluarga membuat ibu hamil sendiri bisa lebih mengatur hidupnya. Sebenarnya penyakit yang berhubungan dengan kehamilan biasanya akan cepat membaik, dengan kenyamanan di rumah dan juga dukungan dari teman terutama keluarga seperti suami, anak-anak dan saudara. ${ }^{14}$

Penelitian yang dilakukan oleh Nia mengenai hubungan status ekonomi, pendidikan, dan dukungan keluarga terhadap pencegahan anemia pada ibu hamil di wilayah kerja 
Puskesmas Tanjung Pinang Kota Jambi tahun 2016. Hasil penelitian ini menunjukkan bahwa dari 50 responden terhadap pencegahan anemia sebanyak 15 responden (30\%) yang baik dan Dukungan keluarga tinggi sebanyak 17 responden (34\%). Hasil penelitian tersebut menjelaskan ada hubungan yang signifikan dukungan keluarga terhadap pencegahan anemia pada ibu hamil di wilayah kerja Puskesmas Tanjung Pinang Kota Jambi tahun 2016. Jika dukungan keluarga kurang atau tidak ada sama sekali bisa mengakibatkan ibu hamil tidak memiliki keinginan untuk mengkonsumsi tablet zat besi. Hal ini disebabkan karena dukungan keluarga (suami) sangat besar pengaruhnya terhadap praktek/tindakan seseorang, terutama ibu hamil yang berada dalam mengkonsumsi zat besi. ${ }^{15}$

Menurut asumsi peneliti, dukungan keluarga merupakan dukungan yang diterima ibu hamil dalam mendorong perilaku pencegahan anemia. Dukungan keluarga kepada ibu hamil dapat dilakukan dengan memberikan kenyamanan, diperhatikan, dihargai dan dicintai. Dengan pemberian dukungan yang bermakna maka ibu hamil akan mengatasi keluhan emesis gravidarum pada masa kehamilan. Dukungan dari keluarga dapat mengurangi stres dimasa kehamilan akibat dari berbagai keluhan kehamilan yang muncul. Dengan adanya dukungan keluarga akan berpengaruh baik terhadap perubahan perilaku ibu hamil dalam mengurangi keluhan tersebut termasuk penyakit anemia ibu hamil.

\section{Kesimpulan}

Berdasarkan hasil penelitian dapat disimpulkan bahwa pencegahan anemia pada ibu hamil dalam kategori kurang baik (57\%), peran tenaga kesehatan kurang baik (55\%), promosi kesehatan kurang baik (63\%), dan dukungan keluarga yang rendah (54\%) dalam pencegahan anemia pada ibu hamil ibu wilayah kerja Puskesmas Bondongan Kota Bogor Tahun 2019.

Ada hubungan yang bermakna antara peran tenaga kesehatan terhadap pencegahan anemia pada ibu hamil di wilayah kerja Puskesmas Bondongan Kota Bogor Tahun 2019 dengan $P$-value sebesar 0.04 dan nilai Odds Ratio 3,67. Ada hubungan yang bermakna antara Promosi Kesehatan terhadap pencegahan anemia pada ibu hamil di wilayah kerja Puskesmas Bondongan Kota Bogor Tahun 2019 dengan P-value sebesar 0.012 dan nilai Odds Ratio 5,00. Ada hubungan yang bermakna antara Dukungan Keluarga terhadap pencegahan anemia pada ibu hamil di wilayah kerja Puskesmas Bondongan Kota Bogor Tahun 2019 dengan P-value sebesar 0.02 dan nilai Odds Ratio 7,62.

\section{Konflik Kepentingan}

Peneliti menyatakan bahwa penelitian ini independen dari konflik kepentingan individu dan organisasi.

\section{Ucapan Terima Kasih}

Terimakasih kepada seluruh pihak yang telah berkontribusi membantu proses penelitian ini.

\section{Pendanaan}

Sumber pendanaan diperoleh dari peneliti. 


\section{SIMFISIS Jurnal Kebidanan Indonesia}

\section{Daftar Pustaka}

1. Kemenkes RI. Survey Demografi Dan Kesehatan Indonesia. Jakarta. Badan Pusat Statistik Indonesia. 2012.

2. WHO. 2014. Maternal Mortality., www.who.int/gho/maternal_health/mortality/maternal_mortality_text.2019

3. Manuaba, I.B.G. Kapita Selekta Penatalaksanaan Rutin Obstetri Ginekologi dan Keluarga Berencana. Jakarta: EGC. 2015

4. Melisa, Fitri, A.D., dan Djauhari, A. Faktor Risiko Yang Berhubungan dengan Kejadian Anemia pada ibu Hamil. Skripsi. 2013

5. Fatmah. Dalam Departemen Gizi (ed). Gizi dan Kesehatan Masyarakat. Jakarta: Departemen Gizi FKM UI. 2012.

6. Ardaningsih. Gmbaran motivasi ibu hamil dalam mengkonsumsi tablet zat besi di Kabupaten Batang. 2014

7. otoatmodjo, Metodologi Penelitian Kesehatan, Jakarta : Rineka Cipta; 2010.

8. Arikunto, Suharsimi. Prosedur Penelitian Suatu Pendekatan Praktek. Jakarta: PT. Rineka Cipta; 2010.

9. Nursalam. Konsep dan penerapan metodologi penelitian ilmu keperawatan. Jakarta: Salemba Medika; 2010.

10. Sugiyono. Metodologi Penelitian Statistik. Jakarta: Rineka Cipta; 2011.

11. Bobak, L. Maternitas, Edisi 4. Jakarta: EGC; 2015.

12. Mubarak, W. I. Promosi Kesehatan Untuk Kebidanan. Jakarta : Salemba Medika

13. Notoadmojo, S. 2016. Metodologi penelitian kesehatan.Jakarta : Rineka Cipta; 2015.

14. Ardaningsih. Gmbaran motivasi ibu hamil dalam mengkonsumsi tablet zat besi di Kabupaten Batang. 2014

15. Nia Nurzia..Hubungan status ekonomi, pendidikan, dan dukungan keluarga terhadap pencegahan anemia pada ibu hamil di wilayah kerja Puskesmas Tanjung Pinang Kota Jambi tahun 2016.STIKes Prima Jambi Program Studi D III Kebidanan. Skrpsi.2016

16. Hulu VT, Pane HW, Tasnim T, Zuhriyatun F, Munthe SA, Hadi S, et al. Promosi Kesehatan Masyarakat. Yayasan Kita Menulis; 2020. 